\title{
Knowledge and practice of folic acid supplementation and impact of income level on awareness among women of child-bearing age in Saudi Arabia
}

\author{
Nawal A Albader ${ }^{1}$, Doaa R Negm², Eman K El Gabry ${ }^{1}$, Mervat M El-Sayed ${ }^{1}$, \\ Shaista Arzoo ${ }^{1 *}$ \\ ${ }^{1}$ Department of Food Science and Nutrition, College of Food and Agriculture Sciences, King Saud University, Riyadh, \\ ${ }^{2}$ Department of Clinical Nutrition, Faculty of Applied Medical Science, Umm Al-Qura University, Riyadh, Saudi Arabia
}

*For correspondence: Email: sarzoo@ksu.edu.sa; Tel: 00966-80-55325

Sent for review: 9 May 2018

Revised accepted: 16 May 2019

\begin{abstract}
Purpose: To investigate the knowledge of Saudi women (pregnant and non-pregnant) about the significance of folic acid (FA) supplementation and to determine how income levels affects this knowledge and its implementation.

Methods: The study was conducted among women of child-bearing age attending Al-Hada Armed Forces Hospital and Khaliss General Hospital (both in Riyadh, Saudi Arabia) for pregnant women and Omm Al-Qura University in Makkah Governorate (Saudi Arabia) for non-pregnant women. A structured questionnaire was used to collect socio-demographic data and to analyze levels of $F A$ knowledge, including general awareness, proper timing of its use, information source, FA benefits, and the perils of FA deficiency. A chi-square test was performed to test the differences between variables.

Results: Analysis of the survey data revealed that $81.1 \%$ of non-pregnant and $91.1 \%$ of pregnant women were aware of the term, FA $(p<0.05)$. Moreover, $71.1 \%$ of the pregnant compared to $35.6 \%$ of non-pregnant women knew that this supplement must be taken before becoming pregnant and this difference was statistically significant $(p<0.05)$. For pregnant women, doctors and previous pregnancies were the main sources of FA knowledge, while mass media was the most frequently reported source for non-pregnant women $(p<0.05)$. Income level was not associated with FA knowledge in either group.

Conclusions: This study illustrates a deficiency in the knowledge and consumption of this important micronutrient in women of childbearing age, the population most in need of this information. Nutrition education should be provided to increase the understanding and practice of FA supplementation periconceptionally and during pregnancy.
\end{abstract}

Keywords: Folic acid supplementation, Pregnancy, Neural tube defect, Income level, Food fortification

This is an Open Access article that uses a fund-ing model which does not charge readers or their institutions for access and distributed under the terms of the Creative Commons Attribution License (http://creativecommons.org/licenses/by/4.0) and the Budapest Open Access Initiative (http://www.budapestopenaccessinitiative.org/read), which permit unrestricted use, distribution, and reproduction in any medium, provided the original work is properly credited.

Tropical Journal of Pharmaceutical Research is indexed by Science Citation Index (SciSearch), Scopus, International Pharmaceutical Abstract, Chemical Abstracts, Embase, Index Copernicus, EBSCO, African Index Medicus, JournalSeek, Journal Citation Reports/Science Edition, Directory of Open Access Journals (DOAJ), African Journal Online, Bioline International, Open-J-Gate and Pharmacy Abstracts

\section{INTRODUCTION}

The nutritional status of women during pregnancy is very important, not just for the quality of their own lives, but also for the wellbeing of their children. Vitamins and minerals support maternal, placental, and fetal metabolic needs and enable healthy gestation. Pregnancy represents a period full of both physical and emotional changes and, as such, the health 
and wellbeing of expectant mothers require extra attention. A well-balanced diet is of utmost importance during this period, particularly because the fetus is nurtured directly through the placenta and, therefore, the fetus' nutritional status is entirely dependent upon that of the mother [1]. Consequently, adequate maternal nutrition is indispensable during pregnancy to ensure both maternal and fetal health [2]. Folic acid (FA), also referred to as vitamin $\mathrm{B} 9$, plays a crucial role in various vital functions including DNA synthesis, methylation and repair, and also serves as a cofactor in numerous biological reactions [3].

Surprisingly, FA intake has remained low [4] despite ample evidence that its consumption periconceptionally and during first trimester of pregnancy significantly decreases the possibility of neural tube defects (NTDs) [5], which lead to congenital malformations including spina bifida and anencephaly [6]. Studies have also revealed that drug therapy is more effective than a balanced diet toward reducing the incidence of NTDs [7,8]. The outcome for fetuses affected with NTDs is bleak: if they are not aborted and manage to survive the neonatal period, they are sure to suffer from life-long disabilities [9]. Maternal consumption of FA before and during the first trimester of pregnancy reduces the risk of NTDs by $50-80 \%$ [10]. Furthermore, FA also prevents congenital heart defects, growth retardation (e.g., low birth weight, smaller head and chest circumferences), preterm births, and cleft palates [11].

Health regulators' recommend at least $400 \mu \mathrm{g}$ of FA per day periconceptionally and in the first trimester (12 weeks) [12]. While both FA and folate are water soluble, FA is a purely synthetic product while folate occurs naturally in food. Like many countries, the Kingdom of Saudi Arabia uses flour fortified with FA, which in turn reduced the incidence of NTDs [13]. The objective of this study was to investigate the cognizance among Saudi women (both pregnant and non-pregnant) of the significance of FA supplementation during pregnancy, the rate of FA consumption, and the effect of income level on these beliefs and practices.

\section{METHODS}

\section{Study design}

A descriptive cross-sectional approach was used to assess the cognizance regarding the significance of FA supplementation among reproductive women. One hundred ten nonpregnant women and one hundred pregnant women were interviewed randomly of which 180 were selected (90 pregnant and 90 nonpregnant) for inclusion in this study. Pregnant women were selected from clinics of Obstetrics Department at (Al-Hada Armed Forces Hospital and Khaliss General Hospital in Riyadh) while non-pregnant women were mostly students and staff of the Omm Al-Qura University in Makkah Governorate.

\section{Inclusion criteria}

All women of reproductive age were eligible for inclusion in this study.

\section{Exclusion criteria}

Women under than 18 years of age, with chronic disease, and active smokers were barred from participation in the present study.

\section{Data collection}

The subjects were interviewed using a structured questionnaire designed by the research team and questionnaire was filled with consent of subjects. This research received approval from Ethical Committee of Department of Applied Medical Sciences, Umm Al Qura University (no. 2017-11-CN01) and followed the guidelines of World Medical Association Declaration of Helsinki of 1964, as amended in 1996 [14]. Oral and written consent was obtained from each participant and they were assured of the confidentiality of the information given by them. The first segment of the survey involved sociodemographic information and the second segment assessed knowledge about FA, including general awareness, the proper timing of its use, the source of their information, the benefits of FA supplementation, and the perils of its deficiency. The answers to these questions were coded as either right or wrong.

\section{Data analysis}

The data are presented as frequencies and percentages. A chi-square test was used to identify relevant differences between variables using the Statistical Package for Social Sciences package for Windows. $P$-values $\leq 0.05$ were regarded as statistically significant.

\section{RESULTS}

\section{Socio-demographic characteristics}

Table 1 presents the socio-demographic characteristics of the subjects. The majority $(\mathrm{n}=$ $83,92.2 \%$ ) of non-pregnant women were $18-24$ 
years old while only $29(32.2 \%)$ of the pregnant women were 18 - 24 years old and $29(32.2 \%)$ of the pregnant women were 25 - 31 years old. Only $8(8.90 \%)$ pregnant women were over 39 years of age. Most of the non- non-pregnant $(\mathrm{n}=$ $87,96.7 \%$ ) women were college graduates while only $46(51.1 \%)$ pregnant women had college degrees. Pregnant women had higher incomes than non-pregnant women. These differences between two groups in terms of age, income level, and education were statistically significant $(p<0.05)$.

\section{Awareness and use of folic acid}

Table 2 shows the awareness of FA in the two groups. The majority of the subjects did not know whether FA is a vitamin, mineral, or protein. Additionally, most were unaware of its dietary sources across both groups. Only 36 (40\%) nonpregnant women and $54(60 \%)$ pregnant women $(p>0.05)$ were cognizant of the significance of FA supplement. The majority of the women did not know that FA deficiency affects the fetus too, rather than just the mother. This difference was statistically significant $(p<0.05)$ between the two groups. Pregnant women answered more questions correctly than their non-pregnant counterparts.

Table 3 contains the sources of information and awareness concerning the time of FA use according to study group. Awareness of FA was higher in pregnant $(\mathrm{n}=82,91.1 \%)$ than in nonpregnant women $(\mathrm{n}=73,81.1 \%)$ though this difference did not reach statistical significance $(p$ $>0.05)$. More pregnant women $(n=68,75.6 \%)$ consumed FA-rich food than non-pregnant women $(n=5,5.6 \%)$. Similarly, compared to non-pregnant women $(n=32,35.6 \%)$, a higher percentage of pregnant women $(n=64,71.1 \%)$ were aware of the appropriate time to begin FA supplementation. This difference was statistically significant $(p<0.05)$, as was the difference in the information sources between the two groups. Doctors and previous experience represented the chief source of information for pregnant women and mass media was the main source of the information reported by non-pregnant women.

Table 4 illustrates the cognizance and use of FA supplements among expecting women during their pregnancy. Although $79(87.8 \%)$ pregnant women consumed supplemental FA during their pregnancy, only $8(8.9 \%)$ of these had accurate information about its recommended dose. Furthermore, the majority of pregnant women ( $\mathrm{n}$ $=64,71.11 \%$ ) had initiated FA supplementation prior to conception.

\section{Association between income level and sources of information and awareness among study participants}

From the data presented in Table 5, it is clear that income level and sources of information (doctors, nurses, previous experiences, books, mass media, etc.) did not affect FA awareness in either pregnant or non-pregnant women.

Table 1: Socio-demographic characteristics of study participants

\begin{tabular}{|c|c|c|c|c|c|c|}
\hline \multirow[t]{2}{*}{ Variable } & \multicolumn{2}{|c|}{$\begin{array}{l}\text { Non-pregnant } \\
\text { women }(n=90)\end{array}$} & \multicolumn{2}{|c|}{$\begin{array}{r}\text { Pregnant } \\
\text { women }(n=90)\end{array}$} & \multirow[t]{2}{*}{$\begin{array}{l}\text { Chi } \\
\text { square }\end{array}$} & \multirow[t]{2}{*}{$P$-value } \\
\hline & $\mathbf{N}$ & $\%$ & $\mathbf{N}$ & $\%$ & & \\
\hline \multicolumn{7}{|l|}{ Age (years) } \\
\hline $18-24$ & 83 & $(92.2)$ & 29 & (32.2) & 7.42 & 0.012 \\
\hline $25-31$ & 6 & $(6.7)$ & 29 & (32.2) & & \\
\hline $32-38$ & 1 & $(1.1)$ & 24 & $(26.7)$ & & \\
\hline $39-45$ & 0 & $(0)$ & 8 & $(8.90)$ & & \\
\hline \multicolumn{7}{|c|}{ Level of education } \\
\hline Illiterate & 0 & $(0)$ & 3 & (3.3) & 48.668 & 0.001 \\
\hline Primary & 0 & (0) & 3 & (3.3) & & \\
\hline Intermediate & 0 & (0) & 6 & $(6.7)$ & & \\
\hline Secondary & 3 & (3.3) & 32 & (35.6) & & \\
\hline University & 87 & $(96.7)$ & 46 & (51.1) & & \\
\hline \multicolumn{7}{|c|}{ Income/month (USD) } \\
\hline$\leq 800$ & 50 & (55.5) & 13 & $(14.4)$ & 35.0 & 0.005 \\
\hline $800-1600$ & 11 & (12.2) & 30 & (33.3) & & \\
\hline $1600-2100$ & 12 & (13.3) & 22 & $(24.4)$ & & \\
\hline$>2100$ & 17 & $(6.7)$ & 25 & $(27.8)$ & & \\
\hline
\end{tabular}


Table 2: Women correctly answering questions on awareness of folic acid use

\begin{tabular}{|l|l|l|l|l|}
\hline Variable & $\begin{array}{l}\text { Non-pregnant } \\
(\mathbf{n = 9 0 )}\end{array}$ & Pregnant (n=90) & Chi square & p-value \\
\hline What is folic acid? & $21(23.3 \%)$ & $33(36.7)$ & 3.81 & 0.051 \\
\hline What is the main source of folic acid? & $31(34.4)$ & $33(36.7)$ & 0.97 & 0.755 \\
\hline $\begin{array}{l}\text { Do you think folic acid supplementation is } \\
\text { required? }\end{array}$ & $36(40)$ & $54(60)$ & 7.20 & 0.007 \\
\hline $\begin{array}{l}\text { What is importance of folic acid during } \\
\text { pregnancy? }\end{array}$ & $41(45.6)$ & $64(71.1)^{`}$ & 12.09 & 0.001 \\
\hline Who suffers from folic acid deficiency? & $30(33.3)$ & $45(50)$ & 5.14 & 0.023 \\
\hline
\end{tabular}

Values in parentheses are percentages

Table 3: Sources of information and awareness about time of use of folic acid among study participants

\begin{tabular}{|c|c|c|c|c|c|c|}
\hline \multirow[t]{2}{*}{ Variable } & \multicolumn{2}{|c|}{$\begin{array}{c}\text { Non-pregnant } \\
\text { women }(n=90)\end{array}$} & \multicolumn{2}{|c|}{$\begin{array}{l}\text { Pregnant women } \\
(n=90)\end{array}$} & \multirow[t]{2}{*}{$\begin{array}{c}\text { Chi } \\
\text { square }\end{array}$} & \multirow[t]{2}{*}{$\begin{array}{r}\boldsymbol{P} \\
\text { value }^{*} \\
\end{array}$} \\
\hline & $N$ & $\%$ & $N$ & $\%$ & & \\
\hline \multicolumn{7}{|c|}{ Have you heard about folic acid? } \\
\hline A. Yes & 73 & $(81.1)$ & 82 & $(91.1)$ & 3.763 & 0.052 \\
\hline B. No & 17 & $(18.9)$ & 8 & $(8.9)$ & & \\
\hline \multicolumn{7}{|c|}{ Do you eat folic acid rich food? } \\
\hline A. Yes & 5 & $(5.6)$ & 68 & $(75.6)$ & 12.59 & 0.00 \\
\hline B. No & 85 & $(94.4)$ & 22 & $(24.4)$ & & \\
\hline \multicolumn{7}{|c|}{ Do you know the proper time for using folic acid supplement? } \\
\hline A. Before conception & 32 & $(35.6)$ & 64 & $(71.1)$ & 22.86 & 0.00 \\
\hline B. After conception & 58 & $(64.4)$ & 26 & $(28.9)$ & & \\
\hline \multicolumn{7}{|c|}{ What is your main source of knowledge about folic acid? } \\
\hline A. Doctor & 11 & $(12.2)$ & 49 & $(54.4)$ & 52.11 & 0.00 \\
\hline B. Nutritionist & 10 & $(11.1)$ & 5 & $(5.6)$ & & \\
\hline C. Nurse & 17 & $(18.9)$ & 1 & $(1.1)$ & & \\
\hline D. Books and Magazines & 9 & $(10)$ & 2 & $(2.2)$ & & \\
\hline E. Previous experiences & 0 & (0) & 15 & (16.7) & & \\
\hline F. Mass media & 31 & $(34.4)$ & 5 & $(5.5)^{\prime}$ & & \\
\hline G. Friends and Relatives & 12 & $(13.3)$ & 13 & $(14.4)$ & & \\
\hline
\end{tabular}

${ }^{*}$ Significant at $\mathrm{P} \leq 0.05$; N-number

Table 4: Awareness and periconceptional use of FA supplement by pregnant women during pregnancy

\begin{tabular}{|c|c|c|c|c|}
\hline Variable & $\mathbf{N}$ & $\%$ & Chi square & $P$-value* \\
\hline \multicolumn{5}{|c|}{ Are you using folic acid supplement during pregnancy? } \\
\hline A. Yes & 79 & $(87.8)$ & \multirow[t]{2}{*}{14.23} & \multirow[t]{2}{*}{0.000} \\
\hline B. No & 11 & (12.2) & & \\
\hline \multicolumn{5}{|c|}{ Did you start folic acid supplementation before conception? } \\
\hline A. Yes & 64 & $(71.11)$ & \multirow[t]{2}{*}{22.8} & \multirow[t]{2}{*}{0.000} \\
\hline B. No & 26 & (28.89) & & \\
\hline \multicolumn{5}{|c|}{ Are you aware of recommended dose of folic acid? } \\
\hline A. Yes & 8 & (8.9) & \multirow[t]{2}{*}{33.8} & \multirow[t]{2}{*}{0.021} \\
\hline B. No & 82 & $(91.11)$ & & \\
\hline
\end{tabular}

*Significant at $p \leq 0.05 ; \mathrm{N}=$ number

\section{DISCUSSION}

The present study examined the awareness and practices of reproductive age women in Saudi Arabia regarding FA supplementation in addition to whether these are impacted by income level. Insufficient levels of maternal FA and folate intake are associated with an increased risk of fetal NTDs (e.g., anencephaly, spina bifida). Daily dietary supplementation of FA $(5 \mathrm{mg})$ periconceptionally reduces this risk and is particularly important for women with previously affected offspring [8]. In Saudi Arabia, the reported rate of NTDs was $0.78 / 1,000$ and $0.82 / 1,000$ live births in the Asir [15] and southwestern [16] regions, respectively. These are consistent with the countrywide decline in the frequency of NTDs (from 1.9/1,000 live births in $1997-2000$ to $0.76 / 1,000$ live births in 2001 2005) due to the fortification of flour with FA [17].

The data collected in this study showed that the majority of expecting mothers $(91.1 \%)$ were aware of FA. This is higher than reported by AlHakeem (58\%) in Riyadh in 2012 [13]. Awareness of FA's importance remains low among women worldwide, including Britain [18] 
Table 5: Association between income level and sources of information on awareness about time of use of FA among study participants

\begin{tabular}{|c|c|c|c|c|c|c|c|c|c|c|c|c|}
\hline \multirow[t]{2}{*}{ Variable } & \multicolumn{4}{|c|}{$\begin{array}{c}\text { Income/month }^{\star \star} \\
\text { Non-pregnant women }(\mathrm{n}=90)\end{array}$} & \multirow[t]{2}{*}{ Chi sq } & \multirow[t]{2}{*}{ P-value* } & \multicolumn{4}{|c|}{$\begin{array}{c}\text { Income/month }{ }^{\star \star}, \text { pregnant women } \\
(\mathrm{n}=90)\end{array}$} & \multirow[t]{2}{*}{ Chi Sq } & \multirow[t]{2}{*}{ P-value* } \\
\hline & $\leq 800$ & $\begin{array}{l}800- \\
1600\end{array}$ & $\begin{array}{l}1600- \\
2100\end{array}$ & $>\mathbf{2 1 0 0}$ & & & $\leq 800$ & $\begin{array}{l}800- \\
1600\end{array}$ & $\begin{array}{l}1600- \\
2100\end{array}$ & $>2100$ & & \\
\hline \multicolumn{13}{|c|}{ Have you heard about folic acid? } \\
\hline A. Yes & 40 & 8 & 10 & 15 & 0.09 & 0.77 & 11 & 28 & 21 & 22 & 0.08 & 0.64 \\
\hline B. No & 10 & 3 & 2 & 2 & & & 2 & 2 & 1 & 3 & & \\
\hline \multicolumn{13}{|c|}{ Do you know the proper time for using folic acid supplement? } \\
\hline $\begin{array}{l}\text { A. Before } \\
\text { conception }\end{array}$ & 16 & 4 & 3 & 9 & 0.05 & 0.38 & 10 & 23 & 13 & 18 & 0.07 & 0.53 \\
\hline B. After conception & 34 & 7 & 9 & 8 & & & 3 & 7 & 9 & 7 & & \\
\hline \multicolumn{13}{|c|}{ What is your main source of knowledge about folic acid? } \\
\hline A. Doctor & 7 & 0 & 1 & 3 & 0.17 & 0.73 & 8 & 17 & 11 & 13 & 0.06 & 0.49 \\
\hline B. Nutritionist & 5 & 0 & 2 & 3 & & & 0 & 3 & 1 & 1 & & \\
\hline C. Nurse & 9 & 1 & 3 & 4 & & & 1 & 0 & 0 & 0 & & \\
\hline $\begin{array}{l}\text { D. Books and } \\
\text { Magazines }\end{array}$ & 6 & 1 & 0 & 2 & & & 0 & 1 & 0 & 1 & & \\
\hline $\begin{array}{l}\text { E. Previous } \\
\text { experiences }\end{array}$ & 0 & 0 & 0 & 0 & & & 1 & 4 & 5 & 5 & & \\
\hline F. Mass media & 17 & 5 & 5 & 4 & & & 1 & 2 & 2 & 0 & & \\
\hline $\begin{array}{l}\text { G. Friends and } \\
\text { Relatives }\end{array}$ & 6 & 4 & 1 & 1 & & & 2 & 3 & 3 & 5 & & \\
\hline
\end{tabular}

${ }^{\star *}$ Significant at $p \leq 0.05 ;{ }^{\star *}$ Income in United States dollar (USD) 
and the United States [19]. In a study of women of reproductive age in Dublin, Ireland, the authors reported that $67 \%$ of the women surveyed were aware of the significance of FA [20]. Relative to the outcomes of the present study, FA cognizance among women in China and Qatar was much lower $(36.0 \%$ and $53.7 \%$, respectively) [21, 22]. A study in Abu Dhabi, United Arab Emirates (UAE) found that $79.1 \%$ of the mothers interviewed had heard of FA and $66.7 \%$ were additionally aware of its importance [23]. In the same study, $46.6 \%$ had accurate information and $36.3 \%$ were cognizant of the dietary sources of folate. The authors stated that doctors were the greatest resource for enhancing women's awareness and understanding of folate's role during pregnancy [23].

In this study, also doctors and previous pregnancies were the primary sources of information regarding $F A$ supplementation for pregnant women and for non-pregnant women; media was the most common source of information. This finding is similar to reports by Bener et al [22] and women living in Vancouver, Canada [24] and Abu Dhabi, UAE [23].

Despite the multitude of empirical evidence in support of the efficacy of periconceptional FA supplementation toward reducing NTDs, the present study found that only $71.1 \%$ of pregnant women were actually following the recommended guidelines. This might be caused by insufficient awareness regarding the importance of FA.

In this study, $36.7 \%$ of pregnant women and $23.3 \%$ of non-pregnant women were aware that FA is a vitamin, which is much lower than a previous report in Burton (West Midlands, England) [25]. Almost half of the pregnant women and one-third of non-pregnant women surveyed here were aware that FA prevents NTDs, which is also lower than the value reported by Sen et al [25] but higher than the results described by others $[19,26]$. The results of the present study showed that both pregnant and non-pregnant women were insufficiently informed regarding FA-rich foods, which is in line with the results reported by Al-Hakeem [13].

In this study, only $36.7 \%$ of expecting mothers were aware of which foods have high levels of $\mathrm{FA}$, which is consistent with the report by $\mathrm{Al}$ Hosani et al [23] who found that only one-third of reproductive-age women were cognizant about the significance of folate in pregnancy and only $28.3 \%$ of them could recall correct dietary sources of FA. Age and education level were the chief factors associated with knowledge of the importance of FA supplementation periconceptionally and during pregnancy. In the present study, no association was found between income level and FA knowledge in both groups. In contrast, a study in Lebanese women found that FA awareness and use correlated with income stability [27]. Similarly, Fatima et al reported an association between income stability and FA awareness and use [28].

Educational strategies in addition to food fortification can be adapted to improve FA awareness levels. However, Al Akhfash et al [29] expressed concern regarding the fortification of food with FA at the population level due to an upsurge in colorectal cancer risk during the FA fortification period [30].

\section{Limitations of the study}

This study has some limitations. The use of the random sampling method resulted in a sample size that was relatively quite small compared to the whole population. Since the survey data were collected from a somewhat smaller region (AlHada Armed Forces Hospital and Khaliss General Hospital for pregnant women and Omm Al-Qura University in the Makkah governorate for non-pregnant women); therefore, the outcomes of this study cannot be generalized to the wider population.

\section{CONCLUSION}

The findings of the present study are suggestive of the lack of adequate awareness of the significance of this essential micronutrient in human reproduction. Nutrition and health education should be provided to women to improve their knowledge of FA to ensure the healthy growth and development of both mother and baby.

\section{DECLARATIONS}

\section{Acknowledgement}

This research project was supported by a grant from the "Research Center of the Female Scientific and Medical Colleges", Deanship of Scientific Research, King Saud University.

\section{Conflict of interest}

No conflict of interest is associated with this work. 


\section{Contribution of authors}

We declare that this work was done by the authors named in this article and all liabilities pertaining to claims relating to the content of this article will be borne by the authors.

\section{Open Access}

This is an Open Access article that uses a funding model which does not charge readers or their institutions for access and distributed under the terms of the Creative Commons Attribution License (http://creativecommons.org/licenses/by/ 4.0) and the Budapest Open Access Initiative (http://www.budapestopenaccessinitiative.org/rea d), which permit unrestricted use, distribution, and reproduction in any medium, provided the original work is properly credited.

\section{REFERENCES}

1. Mudambi R. Your foods and its Utilization- Nutrition of the Mother and Child. IGNOU: CFN 1992; 2: 1-11.

2. Rusescu A. Nutritional Status of pregnant women, children under five years old and school children aged six to seven years. Institute for mother and child care, Romania; 2005.p.1-20.

3. Weinstein SJ, Hartman TJ, Stolzenberg-Solomon $R$, Pietinen P, Barrett MJ, Taylor PR, Virtamo J, Albanes $D$. Null association between prostate cancer and serum folate, vitamin B(6), vitamin B(12), and homocysteine. Cancer Epidemiol Biomarkers Prev 2003; 12: $1271-$ 1272.

4. Hursthouse NA, Gray AR, Miller JC, Rose MC, Houghton $L A$. Folate status of reproductive age women and neural tube defect risk: The effect of long term folic acid supplementation at doses of $140 \mu \mathrm{g}$ and $400 \mu \mathrm{g}$ per day. Nutrients 2011; 3: 49-62.

5. Czeizel AE, Dundas I. Prevention of the first occurrence of neural tube defects by periconceptional folic acid. $N$ Engl J Med 1992; 327: 1832-1835.

6. Kari JA, Bardisi ES, Baitalmal RM, Ageely GA. Folic acid awareness among female college students: neural tube defects prevention. Saudi Med J 2008; 29:1749-51.

7. Berry RJ, Li Z, Erickson JD, Li S, Moore CA, Wang $H$. Prevention of neural-tube defects with folic acid in China. China-U.S. Collaborative Project for Neural Tube Defect Prevention. N Engl J Med 1999; 341: 1485-1490.

8. Botto $L D$, Lisi A, Robert-Gnansia E, Erickson JD, Vollset $S E$, Mastroiacovo P. International retrospective cohort study of neural tube defects in relation to folic acid recommendations: are the recommendations working? BMJ 2005; 330: 571-573.

9. Mitchell LE, Adzick NS, Melchionne J, Pasquariello PS, Sutton LN, Whitehead AS. Spina bifida. Lancet 2004, 364: 1885-1895.
10. Wilson $R D$, Desilets $V$, Wyatt $P$, Langlois $S$, Gagnon $A$, Allen V, Blight $C$, Johnson JA, Audibert F, Brock JA. Pre-conceptional vitamin/folic acid supplementation: The use of folic acid in combination with multivitamin supplement for the prevention of neural tube effects and other congenital anomalies. J Obstet Gynaecol Can 2007; 29: 1003-1013.

11. Rehan M, Mahmood N, Mazhar SB. Knowledge, attitude and practices regarding periconceptional folic acid supplementation in a tertiary care hospital. Ann Pak Inst Med Sci 2015; 11: 172-175.

12. Centers for Disease Control and Prevention. Recommendations for the use of folic acid to reduce the number of cases of spina bifida and other neural tube defects. Morb Mortal Wkly Rep 1992; 41: 1-7.

13. Al-Hakeem MM. Impact of education on knowledge and use of folic acid among Saudi women. Pak J Med Sci 2012; 28: 686-690.

14. World Health Organization. Declaration of Helsinki. Br Med J 1996; 313(7070): 1448-1449.

15. El-Awad Mel-H, Sivasankaran S. Neural tube defects in Southwestern region of Saudi Arabia. Ann Saudi Med 1992; 12: 449-452.

16. Asindi A, Al-Shehri A. Neural tube defects in the Asir Region of Saudi Arabia. Ann Saudi Med 2001; 21: 2629.

17. Safdar OY, Al-Dabbagh AA, Abuelieneen W, Kari JA. Decline in the incidence of neural tube defects after the national fortification of flour (1997-2005). Saudi Med $J$ 2007; 28: 1227-1229.

18. Wild J, Schorah CJ, Maude K, Levene MI. Folate intake in young women and their knowledge of preconceptional folate supplementation to prevent neural tube defects. Eur J Obstet Gynecol Reprod Biol 1996; 27: 185-189.

19. Kloeblen AS. Folate knowledge, intake from fortified grain products, and periconceptional supplementation patterns of a sample of low income pregnant women according to the Health Belief. J Am Diet Assoc 1999; 99: 33-38.

20. Sayers GM, Hughes N, Scallan E, Johnson ZA. Survey of knowledge and use of folic acid among women of child bearing age in Dublin. J Public Health Med 1997; 19: 328-332.

21. Ren A, Zhang L, Li Z, Hao L, Tian Y, Li Z. Awareness and use of folic acid, and blood folate concentrations among pregnant women in northern China - an area with a high prevalence of neural tube defects. Reprod Toxicol 2006; 22: 431-436.

22. Bener A, Al-Marri S, Al-Bast DA. Maternal knowledge, attitude and practice of folic acid intake among Arabian Zatari women. Reproductive Toxicol 2006; 21: 21-25.

23. Al-Hossani H, Abouzeid H, Salah MM, Farag HM, Fawzy E. Knowledge and practices of pregnant women about folic acid in pregnancy in Abu Dhabi, United Arab Emirates. East Mediterr Health J 2010; 16: 402-407.

24. French MR, Barr SI, Milne RL. Folate intakes and awareness of folate to prevent neural tube defects: a 
survey of women living in Vancouver, Canada. J Am Diet Assoc 2003; 103: 1-9.

25. Sen S, Manzoor A, Deviasumathy M, Newton C. Maternal knowledge, attitude and practice regarding folic acid intake during the periconceptional period. Public Health Nutr 2001; 4: 909-912.

26. Sayers GM, Scallan E, McDonnell R, Johnson Z. Knowledge and use of periconceptional folic acid among antenatal patients. Irish Med J 1997; 90: 236-238.

27. Nasr Hage C, Jalloul M, Sabbah M, Adib SM. Awareness and intake of folic Acid for the prevention of neural tube defects among Lebanese women of childbearing age. Matern Child Health J 2012; 16: 258-265.
28. Fatima A, Saif N, Ghani M, Ali S. Knowledge of women; supplementation of folic acid in periconceptional period. Professional Med J 2016; 23: 828-834.

29. Al-Akhfash AA, Abdulla AM, Osman AM, Abdulgafar Jl, Almesned AA. Maternal knowledge and use of folic acid among Saudi females. Saudi Med J 2013; 34: 11731178.

30. Zschabitz S, Cheng TY, Neuhouser ML, Zheng Y, Ray RM, Miller JW, Song X, Maneval DR, Beresford SA, Lane $D$, Shikany JM, Ulrich CM. Vitamin intakes and incidence of colorectal cancer: results from the Women's Health Initiative Observational Study cohort. Am J Clin Nutr 2013; 97: 332-343. 